\title{
Evaluation of patients admitted to the emergency department during religious holidays
}

\section{Dini tatillerde acil servise başvuran hastaların değerlendirilmesi}

\author{
Erdal YAVUZ $@$ @(D), Kasım TURGUT ${ }^{1}$ (D) Umut GÜLAÇTI ${ }^{1}$, Uğur LÖK ${ }^{1}$ (D) İrfan AYDIN ${ }^{1}$ \\ ${ }^{1}$ Adıyaman University, Faculty of Medicine, Department of Emergency Medicine, 02040, Adiyaman-Turkey
}

Atıf gösterme/Cite this article as: Yavuz E, Turgut K, Gülaçtı U, Lök U, Aydın İ. Evaluation of patients admitted to the emergency department during religious holidays. ADYÜ Sağllk Bilimleri Derg. 2021;7(3):192-199. doi:10.30569.adiyamansaglik.976502

\begin{abstract}
Aim: To determine the characteristics of emergency department (ED) presentations during the Ramadan Feast and Feast of Sacrifice.

Materials and Methods: We compared the patients that presented to the ED during the public holiday for the Feast of Sacrifice and the Ramadan Feast in 2018 and 2019.

Results: During the study periods, 37737 people presented to the ED. Compared to the non-holiday time, the patients presenting during the Feast of Sacrifice increased by $14.4 \%$, and those presenting during the Ramadan Feast increased by $9.8 \%(p<0.001$ for both). While there was an increase in hospitalized patients in both holiday periods, this rate was statistically significant only for Feast of Sacrifice (20.8\%, $p=0.0008)$. The number of consultations decreased by $5.6 \%$ during the Feast of Sacrifice and increased by $12.8 \%$ during the Ramadan Feast $(p=0.0002)$.

Conclusion: ED presentations increased during the long religious holiday. While the number of consultations decreased during the Feast of Sacrifice, they increased during the Ramadan Feast.

Keywords: Emergency Service; Crowding; Feast; Holiday.
\end{abstract}

\begin{abstract}
$\ddot{\mathbf{O z}}$
Amaç: Ramazan Bayramı ve Kurban Bayramı'nda acil servis (ED) başvurularının özelliklerini belirlemek.

Gereç ve Yöntem: 2018 ve 2019 Kurban ve Ramazan Bayramı nedeniyle yapılan resmi tatillerde acile başvuran hastaları karşılaştırdık.

Bulgular: Çalışma döneminde 37737 kişi acil servise başvurdu. Bayram dışı zamana göre Kurban Bayramı'nda başvuran hastalar \%14,4, Ramazan Bayramı'nda başvuranlar \%9,8 arttı (tümü için $p<0,001)$. Her iki tatil döneminde de yatan hastalarda artış olurken, bu oran sadece Kurban Bayramı için anlamliydı (\%20,8, $p=0,0008)$. Kurban Bayramı'nda konsültasyon sayıs1 \%5,6 azalırken, Ramazan Bayramı'nda önemli oranda \%12,8 arttı.

Sonuç: Uzun bayram tatilinde acil servis başvuruları artt1. Kurban Bayrami'nda konsültasyonlar azalırken, Ramazan Bayrami'nda arttı.

Anahtar Kelimeler: Acil servis; Kalabalık; Bayram; Tatil.
\end{abstract}

Yazışma Adresi/Address for Correspondence: Erdal YAVUZ, Adıyaman University, Faculty of Medicine, Department of Emergency Medicine, 02040, Adıyaman-Turkey, E-mail: erdal_yavuz15@ hotmail.com

Geliş Tarihi/Received:30.07.2021 Kabul Tarihi/Accepted:26.11.2021 Yayım Tarihi/Published online:31.12.2021

Bu eser, Creative Commons Atıf-GayriTicari 4.0 Uluslararası Lisansı ile lisanslanmıştır. Telif Hakk1 @ 2021 Adıyaman Üniversitesi Rektörlüğü 


\section{Introduction}

Overcrowded emergency departments (ED) are becoming a very serious problem in many countries, and it is necessary to determine factors that lead to this situation and offer solutions to overcome it. ED is a busy service to which many patients present with various clinical symptoms. The critical nature of some cases increased the elderly population, delays in the laboratory and radiological examinations, prolonged consultation period, insufficient number of beds in the hospital, and long public holidays further increase crowding in the ED. ${ }^{1} \mathrm{ED}$ crowding has negative effects on patient satisfaction, service quality, and staff workload.

In Turkey and all Muslim countries, the Feast of Sacrifice and the Ramadan Feast are celebrated at varying times every year. During these celebrations, certain traditions and religious obligations are fulfilled. ${ }^{2}$ The Feast of Sacrifice and the Ramadan Feast normally last for four and three days, respectively. However, in Turkey, public holidays during religious feasts are often extended, reaching nine days including the weekends. The density of ED increases due to the long-term closure of outpatient clinics and family medicine services during the long public holiday periods.

It may be insufficient to evaluate data that include only one holiday period to assess the density of ED because density and crowding may occur on different holidays due to different reasons and factors. There are studies in the literature in which emergency presentations were evaluated only during the Feast of Sacrifice or only during the Ramadan Feast. ${ }^{3-6}$ However, no study compares the density of the ED during the long public holiday times of both feasts with non-holiday times or compares the data between the two feast times. The current study aimed to compare the ED presentations during the Feast of Sacrifice and the Ramadan Feast to those during non-holiday periods, and thus suggest the measures to be taken to prevent overcrowding of these services.

\section{Materials and Methods}

\section{The type of the research}

This research is a retrospective, crosssectional observational study.

\section{The samples of the research}

The study included patients who applied to the Emergency Department of Adryaman University Training and Research Hospital. All patients admitted to the emergency department within the predetermined date range were determined from hospital archives. The hospital was a Level 3 healthcare institution with 25,000-30,000 patient presentations per month. The ED where the study was conducted serves all patients older than 18 years, trauma cases under 18 years, and patients with acute abdomen. Non-traumatic patients under 18 years of age and those with pregnancy-related problems are not accepted. This study was conducted based on the STROBE (Observational studies in epidemiology) statement.

\section{Data collection tools}

To reveal the difference between the ED presentation during the normal (non-holiday) time and those during religious holidays, data were collected during two randomly selected feast periods. The study was conducted in a total of our periods to obtain data from two nine-day public holidays in two consecutive years and two nine-day periods during the non-holiday times in the same years. The details of the evaluated periods are as follows:

Period 1: Normal time from August 4 to 12, 2018

Period 2: Public holiday time from August 18 to August 26, 2018, covering the Feast of Sacrifice

$$
\text { Period 3: Normal time from May } 18 \text { to 26, }
$$
2019

Period 4: Public holiday time from June 1 to 9, 2019 covering the Ramadan Feast

The primary outcome measure was the comparison of the ED presentations between normal times and public holiday times covering the Feast of Sacrifice and the Ramadan Feast. The second outcome measure 
was the comparison of the ED presentations between the two public holidays.

\section{Statistical analysis}

The study data were analyzed using MedCalc Statistical Software for Windows, v12.7.0.0 (Ostend, Belgium). Numerical variables were presented as mean and standard deviation $( \pm \mathrm{SD})$, and categorical variables as numbers and percentages. The binomial test was used to test for differences between the proportions. Categorical variables were analyzed using the Pearson Chi-Square test. Normally distributed data were analyzed by Student's T-test.

\section{The ethical aspect of research}

The study was started after receiving the approval of the Ethics Committee of the University and conducted by the 2008 Declaration of Helsinki principles (Decision number: 2020/7-31). Since it was a retrospective study, the patient consent form was not obtained.

\section{Results}

During the four periods of the study, a total of 37,737 patients presented to the ED. Table 1 shows the comparison of ED presentations between the 2018 and 2019 religious holiday and normal (non-holiday) periods.

Table 1. Comparison of emergency department presentations between the 2018 and 2019 religious holiday and normal (non-holiday) periods.

\begin{tabular}{|c|c|c|c|c|c|c|c|c|}
\hline Charecteristics & $\begin{array}{l}\text { Period } 1(\mathrm{n}, \%) \\
\text { (Normal) }\end{array}$ & $\begin{array}{l}\text { Period } 2(\mathrm{n}, \%) \\
\text { (public holiday, } \\
\text { Feast of Sacrifice) }\end{array}$ & $\begin{array}{l}\text { Total } \\
(\mathrm{n}, \%)\end{array}$ & $P$ value & $\begin{array}{l}\text { Period 3(n, \%) } \\
\text { (Normal) }\end{array}$ & $\begin{array}{l}\text { Period 4(n, \%) } \\
\text { (public holiday, } \\
\text { Ramadan Feast) }\end{array}$ & Total $(\mathrm{n}, \%)$ & $P$ value \\
\hline $\begin{array}{l}\text { Total number of } \\
\text { presentations }\end{array}$ & $8154(42.8)$ & $10895(57.2)$ & $19049(100)$ & $<0.0001 *$ & $8420(45.1)$ & $10268(54.9)$ & $18688(100)$ & $<0.0001 *$ \\
\hline $\begin{array}{l}\text { Admission to } \\
\text { inpatient services }\end{array}$ & $116(39.6)$ & $177(60.4)$ & $293(100)$ & $0.0008 *$ & $167(47.2)$ & $187(52.8)$ & $354(100)$ & $0.344 *$ \\
\hline $\begin{array}{l}\text { Intensive care } \\
\text { admissions }\end{array}$ & $86(51.5)$ & $81(48.5)$ & $167(100)$ & $0.816^{*}$ & $98(52.4)$ & $89(47.6)$ & $187(100)$ & $0.610^{*}$ \\
\hline Referral & $2(40)$ & $3(60)$ & $5(100)$ & $0.634 *$ & $2(28.6)$ & $5(71.4)$ & $7(100)$ & $0.849 *$ \\
\hline Consultation & $465(52.3$ & $424(46.7)$ & $889(100)$ & $0.180^{*}$ & $380(43.6)$ & $492(56.4)$ & 872 & 0.0002 \\
\hline CPR & $5(45.5)$ & $6(54.5)$ & $11(100)$ & $>0.05 * *$ & $2(40)$ & $3(60)$ & $5(100)$ & $>0.05 * *$ \\
\hline Mortality & $5(50)$ & $5(50)$ & $10(100)$ & $>0.05 * *$ & $2(50)$ & $2(50)$ & $4(100)$ & $>0.05 * *$ \\
\hline Laceration repair & $202(38)$ & $330(62)$ & $532(100)$ & $<0.0001 *$ & $235(48.3)$ & $252(51.7)$ & $487(100)$ & $0.509 *$ \\
\hline MRI request & $61(45.9)$ & $72(54.1)$ & $133(100)$ & $0.442 *$ & $79(43.6)$ & $102(56.4)$ & $181(100)$ & $0.119 *$ \\
\hline CT request & $1428(49.7)$ & $1446(50.3)$ & $2874(100)$ & $0.751 *$ & $1356(46.7)$ & $1547(53.2)$ & $2903(100)$ & $>0.05^{*}$ \\
\hline Forensic cases & $285(46.9)$ & $323(53.1)$ & $608(100)$ & $0.148^{*}$ & $221(50.1)$ & $220(49.9)$ & $441(100)$ & $0.957 *$ \\
\hline
\end{tabular}

CPR; Cardiopulmonary resuscitation, MRI; Magnetic resonance imaging, CT; Computerized Tomography

*Binominal test **Pearson Chi-Square test

Compared to the normal time, the number of patients increased by $14.4 \%$ during the Feast of Sacrifice $(p<0.001)$ and by $9.8 \%$ during the Ramadan Feast $(p<0.001)$. The increase in the number of patients was higher for the Feast of Sacrifice than for the Ramadan Feast $(p<0.001)$.
There is no significant difference between the two holiday times in terms of patient age $(53 \pm 12.3$ years for Feast of Sacrifice vs $54 \pm 9.4$ years for Ramadan Feast, $p>0.05$ ). Comparison of ED presentations according to Ramadan Feast and the Feast of Sacrifice is shown in Figure 1. 


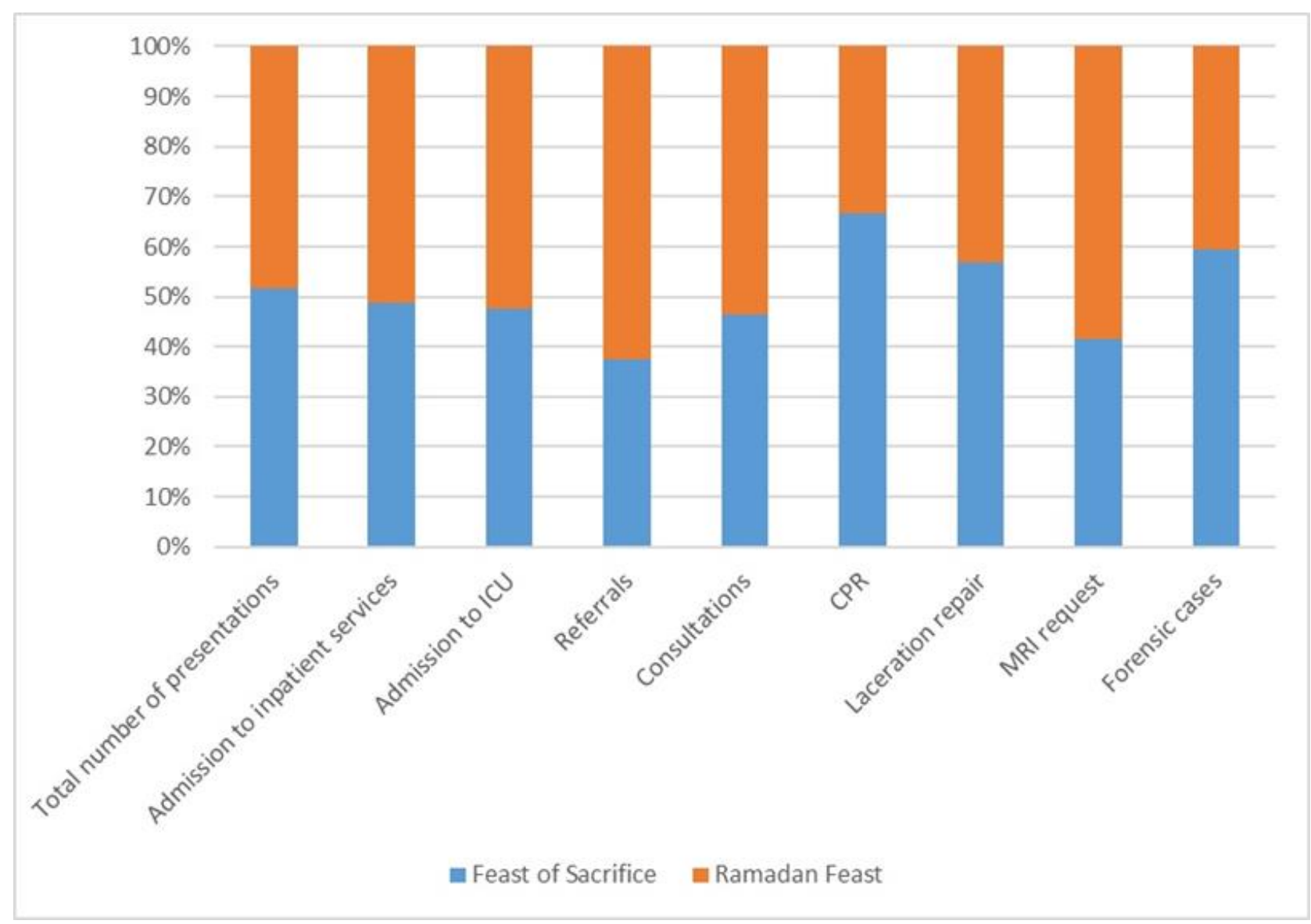

Figure 1. Distribution of patients according to Sacrifice and Ramadan Feast

Abbreviation: ICU; Intensive care unite, CPR; Cardiopulmonary resuscitation, MRI; Magnetic resonance imaging

During the whole study period, a total of 1,001 patients were admitted to intensive care and inpatient services. Compared to normal times, there was an increase the admission to inpatient services during both holidays. But this increase was only statistically significant for Feast of Sacrifice [39.6\% vs $60.4 \%$, $p=0.0008]$. Intensive care admissions decreased in both holidays compared to the normal time. But this increase was not statistically significant $(p>0.05$ for all $)$ (Figure 2).

The number of referrals was not high for all four periods but showed an increase for both feast times. When compared to the normal time, the number of referrals during the Feast of Sacrifice (dif: $20 \%, p=0.634$ ) and the Ramadan Feast (dif: $42.80 \%, p=0.849$ ) did not significantly differ.

A total of 1,761 consultations were requested in all four periods. Of all consultations, $424(46.3 \%)$ was requested during Feast of Sacrifice and 492 (53.7\%) during the Ramadan Feast (dif: $7.0 \%$, $p=0.040$ ). When compared to the normal time, the number of consultations decreased by $5.6 \%$ during the Feast of Sacrifice while it increased by $12.8 \%$ at a significant level during the Ramadan Feast ( $p=0.0002)$.

During the entire study period, Cardiopulmonary resuscitation (CPR) was performed in 16 patients, of whom 13 $(81.3 \%)$ died. Compared to the normal time, there was no increase in the number of CPR performed and the mortality rate during either feast time ( $p>0.05$ for all)

Suturing was applied for skin laceration in a total of 1,019 patients during study periods. The number of suturing procedures increased during the holiday times compared to the normal time (dif: $24 \%$ for the Feast of Sacrifice and dif: $3.4 \%$ for the Ramadan Feast). This increase during the Feast of Sacrifice was statistically significant $(p<0.0001)$.

MRI (Magnetic resonance imaging) and CT (Computerized Tomography) requests increased during the holiday period compared to the normal time. Table 1 shows the 
comparison of $\mathrm{BT}$ and $\mathrm{MR}$ requests during the holiday to normal time.

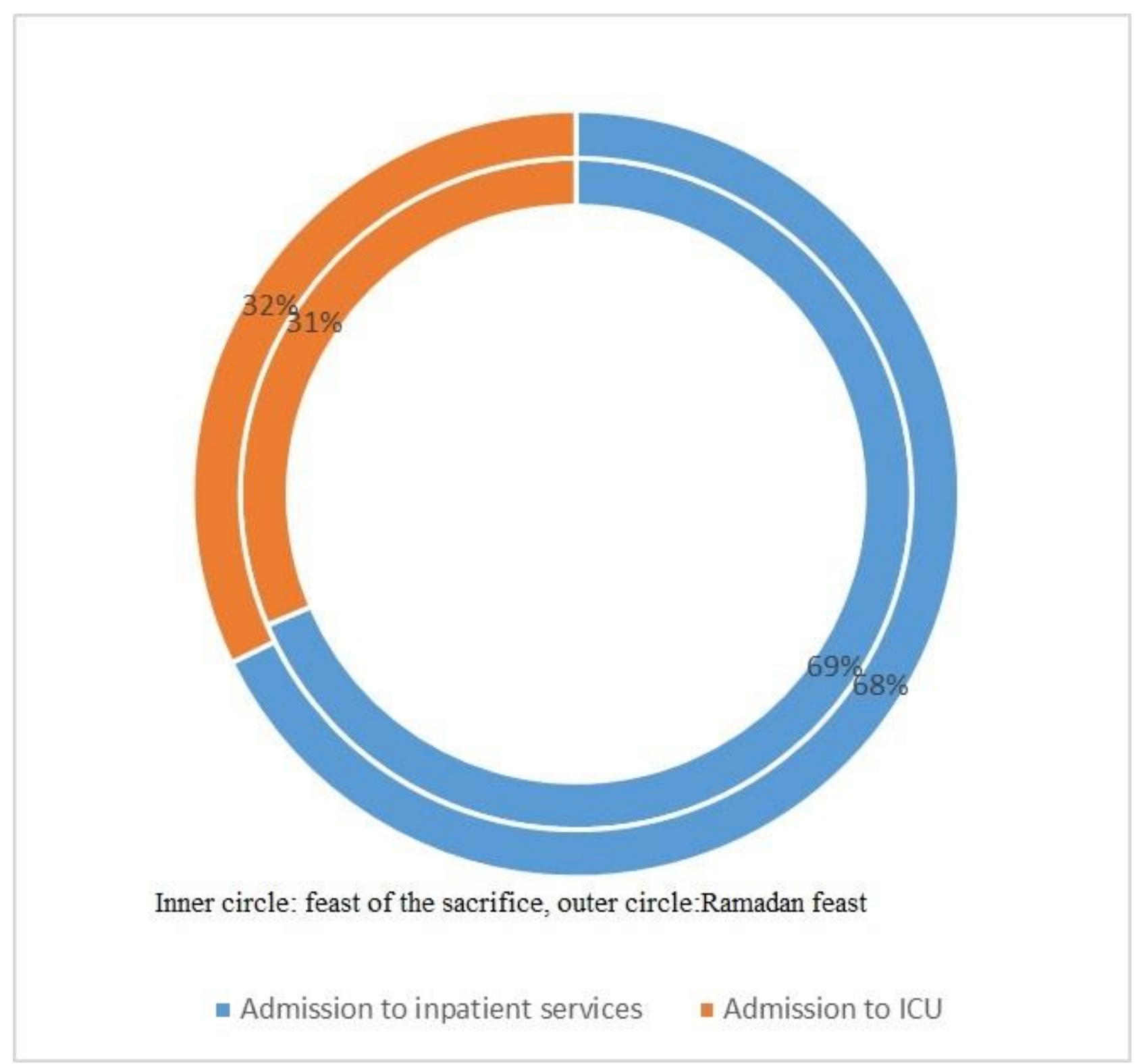

Figure 2. Distribution of patients hospitalized on religious days Inner circle: feast of the sacrifice, outer circle: Ramadan feast Abbreviation: ICU, Intensive care unite

Compared to the normal time, there was no increase in the number of forensic cases during the Ramadan Feast (dif:-0.20\%, $p=0.957$ ). On the contrary, the number of forensic case presentations increased during the Feast of Sacrifice period. But this rate is not at a statistically significant level (dif: $6.20 \%, p=0.148$ ).

\section{Discussion}

To the best of our knowledge, there is no study comparing both the Feast of Sacrifice and the Ramadan Feast holiday and evaluating both in the same study.
ED crowding is increasing in Turkey. Since the number of staff remains the same, the increase in the number of patients in the same physical area leads to a decrease in service quality and result in the burnout of healthcare workers. This burden is further increased by outpatient clinics and first-line healthcare facilities being closed during long public holidays. Previous studies on patient density have found that the number of patients presenting to the ED increased by $10-72.7 \%$ during long holiday periods. ${ }^{6,7}$ In our study, the number of patients increased by $9.8 \%$ during the Ramadan Feast, and by $14.4 \%$ during the Feast of Sacrifice. This is in agreement with previous studies. Excessive 
food consumption and changes in eating habits during long holidays can affect chronic diseases and lead to an increase in emergency presentations. Besides, we consider that the gathering of distant relatives due to longing and the feelings of loyalty and gratitude toward individuals in the place visited may be factors increasing the number of presentations to the ED for non-emergent conditions. Because, even in their slightest complaints, patients' relatives want to be taken to the hospital and they are brought to the ED because there is no other health institution other than the ED.

The number of patients presenting with skin lacerations increases during the Feast of Sacrifice due to the accidents that occur during the slaughtering of animals, especially by careless and inexperienced butchers. Previous studies also showed that laceration cases increased during this feast. ${ }^{8-10}$ However, there are no studies in the literature evaluating the number of laceration repairs performed or that of laceration cases presented to the ED during the Ramadan Feast. In a study conducted by Basturk et al. ${ }^{8}$ hand injuries were frequent especially among novice butchers during the Feast of Sacrifice. In our study, the number of laceration repair procedures increased for both feast periods (by $24 \%$ for the Feast of Sacrifice and 3.4\% for the Ramadan Feast) compared to the normal time; however, this increase was only statistically significant for the former. We consider that surgical intervention areas that can perform laceration repairs can be temporarily increased during the Feast of Sacrifice, and staff reinforcement can be beneficial in terms of increasing patient satisfaction and reducing staff workload.

In a study evaluating the mortality rate during long holidays, Smith et al. ${ }^{11}$ found that the mortality rate was higher during long holidays. In another study, Ofra et al. ${ }^{12}$ reported that the gender-dependent mortality rate increased during the Ramadan month. In contrast, Bol et al. ${ }^{7}$ observed no clear change in the data of real emergency patients such as those requiring CPR or intubation and redtagged patients. In our study, there was no statistically significant difference between the two holiday times and the normal time in terms of the mortality rate and the number of CPR procedures performed. This may indicate that there was no change in the number of actual emergency cases, although the number of patients increased during both holidays.

Considering the hospitalization status of patients during long holidays, previous studies showed that hospitalization increased significantly. ${ }^{5,7}$ However, these studies did not evaluate patient and intensive care services separately. In our study, hospital admissions increased in both holidays compared to the normal time. However, this increase was statistically significant only for the Feast of Sacrifice. In contrast, intensive care admissions decreased in both holiday periods. This may indicate that there may be a change in the attitude of physicians to intensive care or hospital admissions during holiday periods. We consider that even if no emergency patient needs to be hospitalized during holidays, outpatient clinics being closed inevitably increases the number of ED presentations, leading to an increase in the number of hospitalizations and further unnecessary crowding of the ED.

There are no studies directly evaluating the relationship between long public holidays covering religious feasts and forensic case presentations. However, some researchers have reported an increase in the number of presentations for penetrating injuries and traffic accidents during long holidays. ${ }^{5,11,13} \mathrm{In}$ a study conducted by Yildirım et al. ${ }^{5}$ traffic accidents were reported to increase during the Ramadan Feast and the Feast of Sacrifice, and the authors suggested that this could also be a reason for the increase in forensic cases during these periods. On the contrary, Pakdemir et al. ${ }^{14}$ and Dağlar et al. ${ }^{6}$ showed that the increase in traffic accidents was not significant. This was attributed to the absence of high ways between cities. In our study, the increase of forensic cases increased during the Feast of Sacrifice but decreased during the Ramadan Feast compared to the normal time. However, unlike some of the previous studies, we did not determine any statistically significant change during either holiday time. 
The increase in traffic accidents and trauma cases during holidays may be the reason for the increase in forensic cases. Further studies are needed to reveal the direct relationship between the number of forensic case presentations and religious holidays.

In a study conducted by Daglar et al. ${ }^{6}$ The request for $\mathrm{CT}$ was reported to increase during the Feast of the Sacrifice holiday period. Similarly, Bol et al. ${ }^{7}$ found that the number of MRI and CT scans taken increased during the Feast of Sacrifice. In our study, MRI and CT requests increased in both holiday periods. However, unlike the previous two studies, we did not detect any statistical significance in MR requests. The increase in CT requests during the Feast of Sacrifice can be attributed to the increased number of trauma cases related to animal slaughter. We consider that the reason for the higher request for diffusion MRI during the Ramadan Feast may be due to the increase in cerebrovascular events as a result of changes in eating and drinking habits after long-term fasting.

\section{Limitations}

There are some limitations to this study. First, this is a retrospective study. Second, the diagnoses of the patients, the nature of the injuries, and the suture sites could not be evaluated. Third, the length of vacation periods may have an impact on ED admissions and other data. Holiday periods are not equal during the Feast of Sacrifice and the Ramadan Feast. We did not evaluate effects on the study data of duration of religious holidays. There is a need for new studies in which the ED admissions are evaluated according to the length of religious holidays.

\section{Conclusion}

ED presentations vary depending on the type of celebration for which a public holiday is declared. In this study, the number of ED presentations during the Feast of Sacrifice was higher compared to those observed during the Ramadan Feast. Compared to the normal time, the number of patient transfers from the ED to inpatient services increases during both holiday times. The number of consultations is higher during the Ramadan
Feast. There is a need to determine strategies to tackle increased patient density in ED during long holidays. We suggest that long public holidays should not be declared for the Ramadan Feast and the Feast of Sacrifice. Keeping the outpatient clinics of hospitals open during long holiday periods can reduce the presentation of chronic patients to the ED

\section{Ethics Committee Approval}

The protocol was approved by the Ethics Committee of Adiyaman University Faculty of Medicine (Decision date 21/07/2020 Decision nu: 2020/7-31). The research was conducted according to the principles of the Declaration of Helsinki.

\section{Informed Consent}

The requirement for informed consent was waived by the hospital ethics committee since it was a retrospective study.

\section{Author Contributions}

Conception-E.Y, K.T, U.G; Design- U.L, I.A; Supervision-E.Y; Materials- K.T, U.G, U.L; Data Collection and/or Processing- E.Y, K.T; Analysis and/or Interpretation- K.T, U.G, U.L Literature review- K.T, U.G.; Writer-I.A; Critical Review- E.Y, K.T Conflict of Interest No conflict of interest was declared by the authors.

\section{Conflict of Interest}

No conflict of interest was declared by the authors.

\section{Financial Disclosure}

The authors declared that this study has received no financial support.

\section{Peer-review}

Externally peer-reviewed.

\section{References}

1- Karacay P. Emergency department crowding and possible solutions. Journal of Education and Research in Nursing, 2010;7(2):20-25

2- 2- Gürü S, Eşref S, Kadi G, Öktem B, ÇakmakO, Karamercan M. Feast of Sacrifice at the Emergency Department of a University Hospital. Düzce Üniversitesi Sağlı Bilimleri Enstitüsü Dergisi 2019; 9(3): 169-171

3- Bildik F, Yardan T, Demircan A, Uçkan MU, Ergin M, Hacioğlu EG The real victims of the Islamic feast of sacrifice: injuries related to the sacrifice. Turk J Trauma Emerg Surg 2010;16:319-322

4- Dizen H, Koç M, Ocak S, Tez M The sacrifice festival: who is the victim? Ann Emerg Med 2009;53:547-548 
5- Yildirim C, Sozuer EM, Yürümez Y, Ikizceli I, Emergency department services during long-term holidays. Ulus Travma Acil Cerrahi Derg 2000;6:106-109

6- Dagar S, Sahin S, Yilmaz Y, Durak U. Emergency department during long public holidays. Turk J Emerg Med. 2016;14(4):165-71.

7- Bol O, Altuntaş M, Kaynak M, Koyuncu et al. "Uzun Süreli Tatillerin Acil Servis İşleyişine Etkisi". Journal of Anatolian Medical Research 2019;4(1):7-11

8- Basturk M, Katirci Y, Ocak T. Patients admitted to emergency units with injuries related to the four hajj-associated annual animal sacrifice feasts from 2010 to 2013. Ann Saudi Med 2016;36(2):139-142.

9- Avsaroglullari L, Ikizceli I, Sozuer E, Yurumez Y, Kilic S. Hand injuries during a Muslim Sacrifice Festival. Am J Emerg Med 2004;22:508- 509

10- Oktay MM, Bogan M. Analysis of injuries during sacrifice in feast of sacrifice. Bagcilar Medical Bulletin 2018;3(4):55-59

11- Smith S, Allan A, Greenlaw N, Finlay S, Isles C. Emergency medical admissions, deaths at weekends and the public holiday effect. Cohort study. Emerg Med J. 2014;31(1):30-4.

12- Anson O, Anson J, Surviving the holidays: Gender differences in mortality in the context of three Moslem holidays, Sex Roles 1997;37(5/6): 381-399.

13- Zheng W, Muscatello DJ, Chan AC. Deck the halls with rows of trolleys... emergency departments are busiest over the Christmas holiday period. Med J Aust. 2007;187(11):630-3.

14- Pekdemir M, Durukan P, Yildız M, Kavalc1 C. Satisfaction and demographic analysis of patients admitting to emergency department on long holiday periods. Firat Med J 2003;8:149-1. 